\title{
Nutritional Properties and Toxicological Assessment of High Nutrient Biscuit Developed from Blends of Some Cereals and Legume
}

\author{
Oluwole OB*, Elemo GN, Kosoko SB, Adeyoju A, Oyegbami F, Owolabi SO, Taiwo Latona-Tella, Olasehinde TA and Akinwale TE
}

Department of Food Technology, Federal Institute of Industrial Research Oshodi Lagos, Nigeria

\begin{abstract}
This study sought to evaluate the nutritional and antioxidant properties of high nutrient biscuits from some cereals and legume. Toxicological investigations were also carried out on the biscuit developed alongside a commercial biscuit using some selected parameters. Proximate, mineral and vitamin composition of the biscuit were determined. Rats were fed with the high nutrient biscuits, commercial biscuit and normal rat feed for twenty-eight (28) days and were sacrificed by cervical dislocation. The Liver, heart and kidney tissues were analysed for liver (Alanine amino transferase $[A L T]$, Alkaline Phosphatase [ALP], Aspartate amino transferase [AST], Albumin [ALB], Bilirubin [BIL] Total protein (TP)) and kidney (creatinine [CREA] and urea) enzyme and protein levels, including glutathione (GSH), glutathione peroxidase (GPX), glutathione-S- transferase, catalase, superoxide dismutase (SOD) activities, and malondialdehyde (MDA) levels as well as lipid profiles which cover for total cholesterol (TC), triglycerides (TG), high density lipoprotein (HDL) and low density lipoprotein (LDL). Feeding on the biscuits let to the significant $(P<0.05)$ decrease in AST, ALT, ALP, BIL, urea and creatinine levels. However rats fed with the high nutrient biscuit (BRB) had lower concentration of these enzymes and proteins when compared to the conventional biscuit (ARB) and the control (BRC) although there was increase in the ALB and TP content of the BRB group compared to ARB and BRC. Furthermore BRB had significant reduction in the TC, TG, LDL, and HDL concentration followed by the ARB when compared to the BRC groups. Moreover there was significant increase in the levels of the antioxidant enzymes and decrease in malondialdehyde production in the liver, heart and kidney of BRB when compared to other groups. This result indicates high nutritional properties and antioxidant potential of the biscuits. Therefore the high nutrient biscuit could be used as functional food and an adjunct dietary therapy for malnourished children.
\end{abstract}

Keywords: Biscuit; Nutrition; Anti-oxidant; Malnourish; Children

\section{Introduction}

Malnutrition is a major health problem common to underdeveloped and developing countries of the world. It is a major cause of death and accounts for fifty percent deaths in children less than five years [1]. Recent reports have shown that 43 percent of children are stunted all over the world due to poverty and inaccessibility to good food. Moreover stunting is commonly used as an index for long-term chronic nutritional deficiency [2]. Nutritional deficiency has been linked with high free radical generation [3]. Free radicals are capable of inducing oxidative stress which has been implicated in the development and progression of some diseases such as diabetes, cardiovascular and neurodegenerative diseases $[4,5]$.

One of the Major interventions for the treatment and/or management of malnutrition is fortification of food with essential nutrients [6]. Many food products such as bread, biscuit, snacks and confectioneries are vehicles used to deliver major nutrients to the body [7]. Development of fortified biscuit is widely acceptable since it is a good vehicle of supplementation with proteins, carbohydrate, minerals and fats including phytochemicals. This major characteristic is due to the fact that biscuits are ready to eat, popular, easily accessible, cheap, has high nutrient density and long shelf life. Biscuit are usually produced with different ingredients such as flour, shortening (margarine), sweeteners (sugar) and milk. The type of cereals and other constituents present in a biscuit determines its nutritional quality and medicinal properties.

Previous reports have shown that cereals and legumes such as sorghum, maize and soybean contain appreciable levels of micro and macro nutrients including phytochemicals which can help to combat malnutrition as well as prevent oxidative stress and diseases associated with malnutrition $[8,9]$. This study sought to evaluate the nutritional properties of high nutrient biscuit developed from sorghum, maize and soybean flour as well as assessing its toxicological effects.

\section{Materials and Methods}

\section{Materials}

Soybean, sorghum, maize, wheatflour, sugar, salt, fat, Sodium bicarbonate (baking powder), lecithin and milk were purchased from the main market in Mushin Lagos State Nigeria.

\section{Methods}

Production of biscuit: Biscuits were produced at laboratory scale using the method of Ayo [10] with a slight modification.

Determination of nutritional composition: Nutrition composition of the biscuit was determined using established methods. Proximate and mineral composition was determined using the method of AOAC [11]. Vitamin analysis was also carried via high performance liquid chromatography (HPLC) using the method of AOAC [11].

Sensory evaluation: Sensory evaluation was conducted on the developed biscuit at laboratory scale according to the method described [12]. It was compared to readily available commercial biscuit. They were given the reference codes $\mathrm{HNB}$ and $\mathrm{CB}$ for the developed and

*Corresponding author: Oluwole Bolanle Oluwatoy, Department of Food Technology, Federal Institute of Industrial Research, Oshodi Lagos, Nigeria, Tel: +2348033044961; E-mail: oluwatoyinoluwole575@yahoo.com

Received September 30, 2015; Accepted November 25, 2015; Published December 01, 2015

Citation: Oluwole OB, Elemo GN, Kosoko SB, Adeyoju A, Oyegbami F, et al (2015) Nutritional Properties and Toxicological Assessment of High Nutrient Biscuit Developed from Blends of Some Cereals and Legume. J Nutr Disorders Ther 5 176. doi:10.4172/2161- 0509.1000176

Copyright: $\odot 2015$ Oluwole OB, et al. This is an open-access article distributed under the terms of the Creative Commons Attribution License, which permits unrestricted use, distribution, and reproduction in any medium, provided the original author and source are credited. 
Citation: Oluwole OB, Elemo GN, Kosoko SB, Adeyoju A, Oyegbami F, et al. (2015) Nutritional Properties and Toxicological Assessment of High Nutrient Biscuit Developed from Blends of Some Cereals and Legume. J Nutr Disorders Ther 5: 176. doi:10.4172/2161- 0509.1000176

Page 2 of 5

commercial biscuit respectively. The coded samples were presented to a 10-men panelist to evaluate for the attributes: colour/appearance, taste, after taste, mouth feel, crispiness, crunchiness texture, flavour, aroma, and overall acceptability. Scores were given to the scales: (1) extremely unacceptable (2) very unacceptable (3) moderately unacceptable (4) slightly unacceptable (5) neither acceptable nor unacceptable (6) slightly acceptable (7) moderately acceptable (8) very acceptable and (9) extremely acceptable.

Animal experiment: Male albino rats (25) with mean weight 95 $\pm 5.32 \mathrm{~g}$ and mean age 3-4 weeks were divided into three groups BRC $\mathrm{CB}$ and $\mathrm{HNB}$ and housed in rat cages. They were allowed access to water and feed diet ad libitum for them to acclimatize to laboratory conditions. After this period, the control animals (BRC) were continues on the commercial feed uninterrupted, while CB animals were placed on commercial biscuits and group $\mathrm{C}$ on the baked soy biscuit. The animals were fed for 28 days with the appropriate feeds and water ad libitum. The animals were weighed immediately before commencement of the feeding experiment and afterwards at a week intervals for the remaining days the was carried out.

Determination of hematological parameters: Hematology profile, which covers hemoglobin level (HGB), packed cell volume (PCV), red blood cell (RBC) count, white blood cell count (WBC), platelets (PLT) was determined using a Synchron CX5 autoanalyzer according to the manufacturer's protocol.

Determination of serum biochemistry (liver and renal function enzymes, lipid profile): Blood serum was used for the evaluation of biochemical parameters, including urea, creatinine, total bilirubin, total protein, albumin, alanine aminotransferase, aspartate aminotransferase, and alkaline phosphatase, using commercial kits from Randox Laboratories, UK, according to the manufacturer's protocol. Serum's total cholesterol, triglyceride, and high-density lipoprotein (HDL) levels were also measured via enzymatic colorimetric method using Randox kits [13].

Determination of oxidative stress parameters: Lipid peroxidation was determined by measuring malondialdehyde (MDA) formed by thiobCBituric acid reaction (TBAR). Catalase (CAT) activity was estimated by measuring the rate of decomposition of $\mathrm{H}_{2} \mathrm{O}_{2}$ using the method of Aebi [14]. The level of superoxide dismutase (SOD) activity was determined [15]. While the method of Ellman [16] was adopted in estimating the activity of reduced glutathione (GSH).

Data analysis: Results were pooled and statistical significance was established using one-way analysis of variance, and data were reported as mean \pm standard error. Significant difference was established at $p<0.05$. Statistical analyses were carried out using SPSS for Windows, version 17.0 (SPSS Inc., Chicago, IL).

\section{Results and Discussion}

There are indications that foods and nutrients contribute to normal functioning of the body. Inclusion of cereals and legumes with bioactive compounds and nutraceuticals in human nutrition has been shown to alleviate malnutrition and its associated diseases such as neurodegenerative diseases, diabetes, diverticulosis and cardiovascular diseases [17]. The proximate composition of the high nutrient density biscuit as shown in Table 1 revealed appreciable amounts of carbohydrate (59.34\%), protein (17.50\%) and high calories (440.7 kcal). Table 2 shows the mineral composition of the high nutrient density biscuit. Minerals such as iron $(5.9 \mathrm{mg} / \mathrm{g})$, Magnessium $(39.0 \mathrm{mg} / \mathrm{g})$, Phosphorus (145.1 mg/g), Zinc (1.2 mg/g), Selenium ( $4.9 \mathrm{mg} / \mathrm{g})$ and
Calcium $(191.0 \mathrm{mg} / \mathrm{g})$. Furthermore, Table 3 shows the presence of vitamin $B_{1}(0.12 \mathrm{mg} / \mathrm{g}), B_{2}(0.10 \mathrm{mg} / \mathrm{g}), B_{6}(1.50 \mathrm{mg} / \mathrm{g}), B_{6}(0.10 \mathrm{mg} /), B_{12}$ $(40.10 \mathrm{mg} / \mathrm{g})$ and $\mathrm{D}(1.30 \mathrm{mg} / \mathrm{g})$. Furthermore, sensory characteristics of the laboratory scale developed biscuit and a commercial biscuit were done using parameters such as color/appearance, taste, after taste, mouthfeel, texture, crispiness, crunchiness, flavour and overall acceptability. Similar result was obtained in both biscuit samples over a period of five months as shown in Table 4 . There was decrease in the sensory characteristics over the months.

The results of the haematological indices are shown in Table 5. There was no significant $(\mathrm{P}<0.05)$ difference in all the hematological parameters that were determined in the control, $\mathrm{CB}$ and HNB groups. This shows that feeding on the biscuit does not pose any risk of diseases since increase or decrease in any of these parameters indicate

\begin{tabular}{|c|c|}
\hline Parameters & HNB \\
\hline Mositure (\%) & $5.9 \pm 0.35$ \\
\hline Protein (\%) & $14.9 \pm 0.25$ \\
\hline Crude fat (\%) & $17.11 \pm 0.23$ \\
\hline Ash (\%) & $2.04 \pm 0.18$ \\
\hline CCBohydrate (\%) & $59.34 \pm 9.7$ \\
\hline Energy (K cal) & $440.7 \pm 2.25$ \\
\hline
\end{tabular}

HNB- High nutrient biscuit developed from soybean. Values represent means of triplicate readings.

Table 1: Proximate composition of high nutrient biscuit.

\begin{tabular}{|c|c|}
\hline Minerals & HNB \\
\hline Iron & $5.9 \pm 0.06$ \\
\hline Magnesium & $39.0 \pm 0.25$ \\
\hline Phosphorous & $145.1 \pm 2.2$ \\
\hline Zinc & $1.2 \pm 0.05$ \\
\hline Selenium & $4.9 \pm 0.12$ \\
\hline Calcium & $191.0 \pm 1.2$ \\
\hline
\end{tabular}

HNB - high nutrient biscuit. Values represent means of triplicate readings.

Table 2: Mineral composition of high nutrient biscuit ( $\mathrm{mg} / \mathrm{g})$.

\begin{tabular}{|c|c|}
\hline Vitamins & HNB \\
\hline $\mathrm{B}_{1}$ & $0.12 \pm 0.0002$ \\
\hline $\mathrm{B}_{2}$ & $0.10 \pm 0.0001$ \\
\hline $\mathrm{B}_{3}$ & $1.50 \pm 0.0003$ \\
\hline $\mathrm{B}_{6}$ & $0.10 \pm 0.0005$ \\
\hline $\mathrm{D}$ & $1.30 \pm 0.0003$ \\
\hline $\mathrm{B}_{12}$ & $40.10 \pm 2.14$ \\
\hline
\end{tabular}

HNB - High nutrient biscuit. Values represent means of triplicate readings.

Table 3: Vitamin composition of high nutrient biscuit ( $\mathrm{mg} / \mathrm{g})$.

\begin{tabular}{|c|c|}
\hline Biscuit attributes & HNB \\
\hline Colour/Apperance & $7.4 \pm 0.67$ \\
\hline Taste & $7.2 \pm 0.69$ \\
\hline After taste & $6.54 \pm 0.55$ \\
\hline Mouthfeel & $6.26 \pm 0.54$ \\
\hline Texture & $7.02 \pm 0.78$ \\
\hline Crispiness & $6.50 \pm 0.67$ \\
\hline Crunchiness & $6.44 \pm 0.62$ \\
\hline Flavour & $6.96 \pm 0.81$ \\
\hline Overall acceptability & 6.72 \\
\hline
\end{tabular}

HNB - High nutrient biscuit. Note: Values $=$ mean $\pm S D ; n=10$.

Table 4: Sensory attributes of developed biscuits. 


\begin{tabular}{|c|c|c|c|}
\hline Parameters & Control & CB & HNB \\
\hline WBCx109/L & $4.71 \pm 0.52^{\mathrm{a}}$ & $4.42 \pm 0.43^{\mathrm{a}}$ & $4.28 \pm 0.74^{\mathrm{a}}$ \\
\hline RBCx1012/L & $7.36 \pm 0.81^{\mathrm{a}}$ & $6.93 \pm 0.85^{\mathrm{a}}$ & $7.10 \pm 0.92^{\mathrm{a}}$ \\
\hline Hgb g/dL & $14.62 \pm 1.53^{\mathrm{a}}$ & $13.1 \pm 1.93^{\mathrm{a}}$ & $14.7 \pm 1.81^{\mathrm{a}}$ \\
\hline $\mathrm{PCV}(\%)$ & $41.9 \pm 4.21^{\mathrm{a}}$ & $41.7 \pm 3.50^{\mathrm{a}}$ & $40.9 \pm 2.80^{\mathrm{a}}$ \\
\hline $\mathrm{PItx} 109 / \mathrm{L}$ & $821 \pm 37.32^{\mathrm{a}}$ & $876 \pm 40.56^{\mathrm{a}}$ & $808 \pm 35.32^{\mathrm{a}}$ \\
\hline $\mathrm{MCV}(\mathrm{f} \mathrm{I})$ & $63.0 \pm 5.51^{\mathrm{a}}$ & $65.2 \pm 6.22^{\mathrm{a}}$ & $64.1 \pm 6.83^{\mathrm{a}}$ \\
\hline MCH (pg) & $19.8 \pm 1.42^{\mathrm{a}}$ & $19.4 \pm 1.30^{\mathrm{a}}$ & $20.0 \pm 1.25^{\mathrm{a}}$ \\
\hline MCHC (g/dL) & $31.7 \pm 3.80^{\mathrm{a}}$ & $31.5 \pm 2.43^{\mathrm{a}}$ & $30.8 \pm 3.30^{\mathrm{a}}$ \\
\hline
\end{tabular}

Values represent means of triplicate readings. Values with the same letter along the rows are not significantly $(P<0.05)$ different. $W B C=$ white blood cell; $R B C=$ red blood cell; Hgb=Hemoglobin; $\mathrm{PCV}=$ Packed cell volume; PIt= Platelet; $\mathrm{MCV}=$ Mean corpuscular volum;, $\mathrm{MCH}=$ mean corpuscular hemoglobin, $\mathrm{MCHC}=$ mean corpuscular hemoglobin concentration. $\mathrm{ARB}=$ rats fed with commercial biscuit $\mathrm{BRB}=$ rat fed with FIIRO biscuit.

Table 5: Hematological profile of the experimental groups.

\begin{tabular}{|c|c|c|c|}
\hline Parameters & BRC & CB & HNB \\
\hline ALT $(\mu / \mathrm{L})$ & $40.56 \pm 13.2^{\mathrm{a}}$ & $21.4 \pm 8.63^{\mathrm{c}}$ & $20.63 \pm 10.2^{\mathrm{c}}$ \\
\hline AST $(\mathrm{u} / \mathrm{L})$ & $210.01 \pm 15.8^{\mathrm{a}}$ & $224.8 \pm 18.5^{\mathrm{a}}$ & $232.83 \pm 16.4^{\mathrm{a}}$ \\
\hline ALP $(\mu / \mathrm{L})$ & $42.86 \pm 10.3^{\mathrm{a}}$ & $66.5 \pm 5.32^{\mathrm{c}}$ & $65.2 \pm 8.53^{\mathrm{c}}$ \\
\hline ALB $(\mathrm{g} / \mathrm{L})$ & $16.76 \pm 4.21^{\mathrm{a}}$ & $21.4 \pm 3.11^{\mathrm{a}}$ & $20.63 \pm 2.91^{\mathrm{a}}$ \\
\hline TP $(\mathrm{g} / \mathrm{L})$ & $31.66 \pm 10.5^{\mathrm{a}}$ & $45.8 \pm 10.5^{\mathrm{a}}$ & $38.42 \pm 9.7^{\mathrm{a}}$ \\
\hline BIL $(\mu \mathrm{mol} / \mathrm{L})$ & $0.36 \pm 0.10^{\mathrm{a}}$ & $1.56 \pm 0.50^{\mathrm{b}}$ & $0.46 \pm 0.15^{\mathrm{a}}$ \\
\hline
\end{tabular}

BRC-Control, CB- Commercial biscuit, HNB- High nutrient biscuit. Value represents means of triplicate readings. Values with same superscript along the rows are not signicantly different at $\mathrm{P}>0.05$.

Table 6: Blood chemistry parameter for liver function.

a disease state such as anaemia. Liver enzymes are biomarkers that indicate liver function. Increased levels of ALT, AST, and ALP are associated with hepatic tissue dysfunction and damage. Figure 5 shows the determination of liver function enzymes in the experimental rats. The result shows that ALT levels decreased significantly in CB and HNB when compared to the control (BCR). However, there was no significant $(\mathrm{P}>0.05)$ difference in the AST and ALP levels in the control $\mathrm{CB}$ and HNB. This result indicates that feeding on this biscuit does not induce liver damage. This result agrees with what was obtained by Garg [18] in which Phyllanthus fraternus extract reduced liver enzyme levels in diabetic subjects.

The liver is the major source of some serum proteins and these proteins are useful indicators of liver function. Table 6 shows the total protein and albumin levels in the experimental rats. There was no significant difference in the albumin and total protein levels across the groups. Some reports have shown that serum levels of these proteins are low in some hepatic diseases [19]. Moreover albumin synthesis is affected by liver diseases and nutritional deficiencies [20]. The determination of bilirubin levels in the experimental rats is shown in Table 6. Although there was no significant $(\mathrm{P}<0.05)$ difference in the bilirubin levels of the control and HNB groups, CB had significantly higher bilirubin levels than other experimental groups. Bilirubin is a product of Haemoglobin breakdown and serves as a diagnostic marker of liver and blood disorders. Serum bilirubin levels are usually high in several clinical conditions [21]. The decrease in bilirubin levels obtained in this study revealed that prolong feeding on high nutrient biscuit protected the liver from injuries. The observed reduction in bilirubin levels could be attributed to present phenolic compounds present in soybean and sorghum. However, high bilirubin levels observed in CB groups may be due to the absence of these phytochemicals. Furthermore, serum levels of urea and creatinine are used as indicators for kidney function.
They are by-products of protein metabolism required for excretion via the kidney. High levels of these parameters in experimental rats show kidney dysfunction. In this study, urea and creatinine levels of $\mathrm{CB}$ and HNB were significantly lower than that of the control as shown Table 7. These results indicate normal renal function. Increased plasma lipids is associated with several cardiovascular disorders [22,23]. High levels of cholesterol and triglyceride is majorly due to lipolysis, increase in mobilization of free fatty acids from peripheral depots $[18,24]$. Increase in LDL will also cause cholesterol to be deposited on the arterial wall and aorta which eventually disrupt blood flows. In this present study, there was significant decrease in TC, TG and LDL plasma levels in $\mathrm{CB}$ and HNB when compared to the control as shown in Figure 1. This result shows that feeding on the high nutrient biscuit will prevent hyperlipidaemia in experimental subjects which will reduce the risk of cardiovascular diseases.

Oxidative stress is an imbalance between the production of reactive oxygen species (ROS) and the cell's ability to reduce ROS, detoxify reactive intermediates and repair damage that may occur in cellular molecules. This imbalance may occur as a result of increased ROS production, and decrease in antioxidant enzymes levels. Major biomarkers of oxidative stress include changes in antioxidant enzymes (GSH, SOD CAT) activities and accumulation of lipid peroxidation products such as Malondialdehyde (MDA) [25]. GSH metabolism is an important antioxidative defense mechanism that reduces the level of hydrogen peroxides in cells thereby preventing oxidative damage and cell death [26]. Figure 2 revealed that GSH levels increased in $\mathrm{CB}$ and HNB heart, liver and kidney when compared to the control. Furthermore, SOD activities also increased significantly in the liver and kidney of CB and HNB as shown in Figure 3. However, HNB had lower SOD activity in the rats' heart than CB but was still higher than that of the control. SOD catalyses the dismutation of highly reactive superoxides to oxygen and hydrogen peroxide [27]. Catalase protects the cells from hydrogen peroxide produced from the reaction catalysed by SOD thereby preventing further breakdown of $\mathrm{H}_{2} \mathrm{O}_{2}$ to a more reactive $\mathrm{OH}$ radical [27]. The result obtained in Figure 4 shows that HNB had significantly $(\mathrm{P}<0.05)$ higher catalase activities than $\mathrm{CB}$ and BRC. These results revealed that HNB had higher antioxidant enzyme

\begin{tabular}{|c|c|c|c|}
\hline Parameters & Control & CB & HNB \\
\hline CREA $(\mu \mathrm{m} / \mathrm{L})$ & $29.93 \pm 6.5^{\mathrm{a}}$ & $21.72 \pm 3.9^{\mathrm{a}}$ & $15.97 \pm 2.5^{\mathrm{c}}$ \\
\hline Urea $(\mathrm{mmol} / \mathrm{L})$ & $1.66 \pm 0.8^{\mathrm{a}}$ & $0.93 \pm 0.41^{\mathrm{a}}$ & $1.36 \pm 0.6^{\mathrm{a}}$ \\
\hline
\end{tabular}

BRC-Control, CB- Commercial biscuit, HNB- High nutrient biscuit. Value represents means of triplicate readings. Values with same superscript along the rows are not signicantly different at $\mathrm{P}>0.05$.

Table 7: Blood chemistry parameter for kidney function.

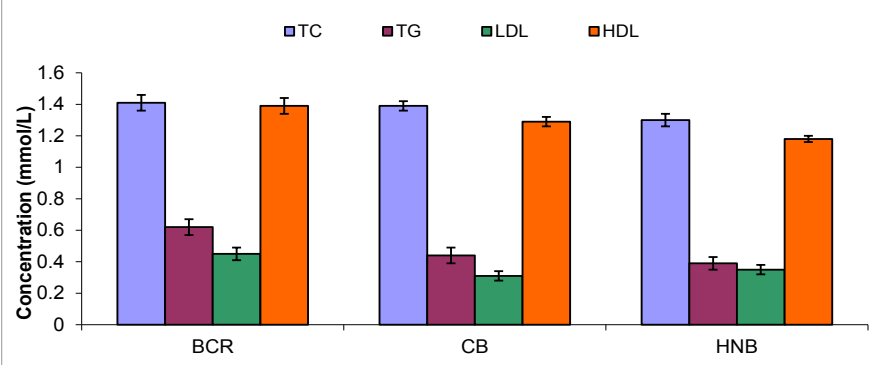

Figure 1: Lipid profile of the experimental groups. TC= Total cholesterol, TG= Triglyceride, $L D L=L o w$ density lipoprotein, $\mathrm{HDL}=$ high density lipoprotein, $\mathrm{BCR}=$ Control group, $\mathrm{CB}=$ rats fed with commercial biscuit, $\mathrm{HNB}=$ Rats fed high nutrient biscuit. Data are presented as mean $\pm S D, n=6$. 
Citation: Oluwole OB, Elemo GN, Kosoko SB, Adeyoju A, Oyegbami F, et al. (2015) Nutritional Properties and Toxicological Assessment of High Nutrient Biscuit Developed from Blends of Some Cereals and Legume. J Nutr Disorders Ther 5: 176. doi:10.4172/2161- 0509.1000176

Page 4 of 5

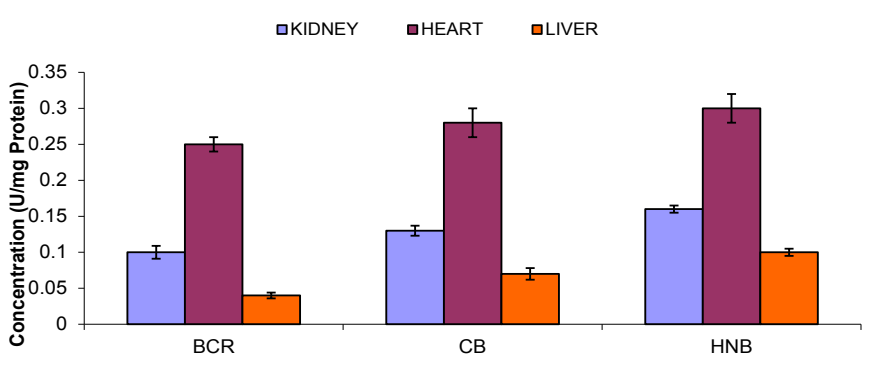

Figure 2: Glutathione (GSH) activities in rat kidney, heart and liver tissues. Data=mean $\pm S D, n=3$. Statistically significant $(p<.05)$ between groups. $B C R=$ Control group, $\mathrm{CB}=$ rats fed with commercial biscuit, $\mathrm{HNB}=$ Rats fed with high nutrient biscuit. Data are presented as mean $\pm \mathrm{SD}, \mathrm{n}=6$.

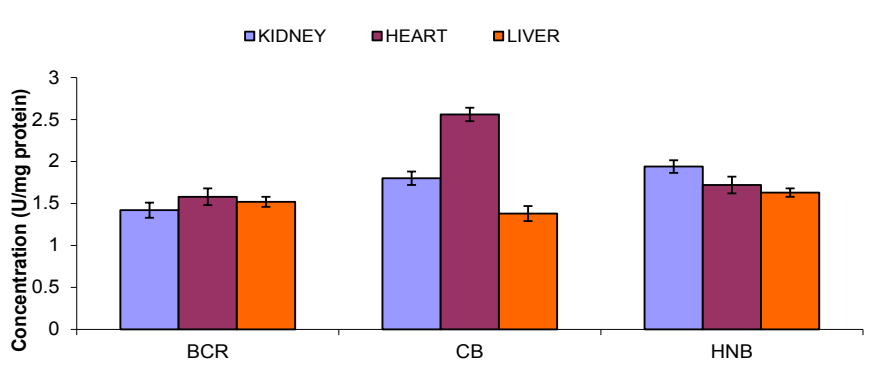

Figure 3: Superoxide dismustase (SOD) activities in rat kidney, heart and liver tissues. Data are presented as mean $\pm S D, n=6$. Statistically significant $(p<0.05)$ between groups. $B C R=$ Control group, $C B=$ rats fed with commercial biscuit, HNB= Rats fed with high nutrient biscuit.

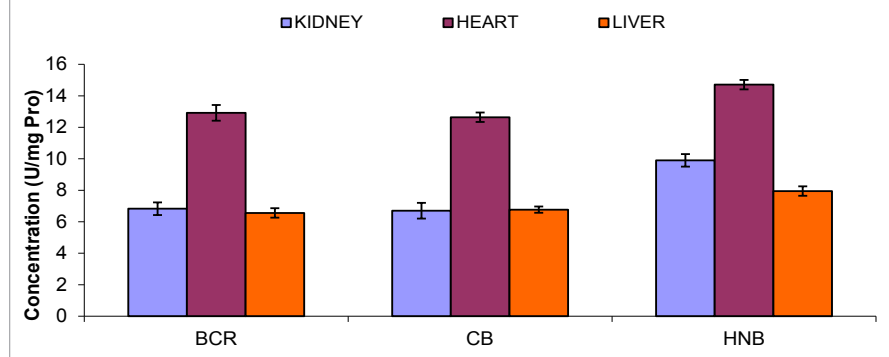

Figure 4: Catalase (CAT) activities in rat kidney, heart and liver tissues. Statistically significant $(p<0.05)$ between groups. $B C R=$ Control group, BCR= Control group, $\mathrm{CB}=$ rats fed with commercial biscuit, $\mathrm{HNB}=$ Rats fed with high nutrient biscuit. Data are presented as mean $\pm \mathrm{SD}, \mathrm{n}=6$.

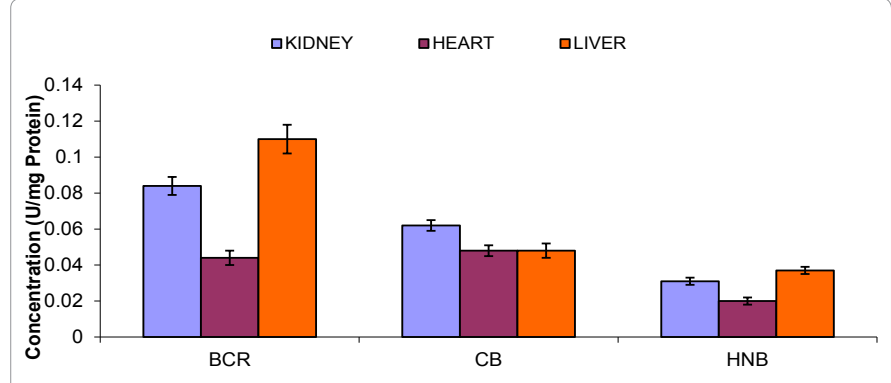

Figure 5: Malondialdehyde (MDA) levels in rat kidney, heart and liver tissues. Statistically significant $(p<.05)$ between groups. $B C R=$ Control group, $C B=$ rats fed with commercial biscuit, $\mathrm{HNB}=$ Rats fed with high nutrient biscuit. Data are presented as mean $\pm S D, n=6$. activities than CB. Higher antioxidant enzyme activities will reduce oxidative stress which has been associated with severe malnutrition.

Malondialdehyde (MDA) is one of the products of lipid peroxidation. Its presence in tissues indicates oxidative stress. Results from this study showed that feeding on the biscuit reduced MDA levels in the heart, liver and kidney. However, MDA levels in HNB were significantly lower than CB and BRC (Figure 5). Nwozo and Oyinloye also reported decrease in MDA levels in rats' liver which was caused by aqueous extract of Afromomum melegueta [28].

\section{Conclusion}

The nutritional properties, high antioxidant activity and protective effects of the high nutrient biscuit on liver and kidney suggests its potential as functional food and adjunct therapy for the management and/or treatment of malnutrition and malnutrition-induced oxidative stress.

\section{References}

1. Aly GS, Shaalan AH, Mattar MK, Ahmed HH, Zaki ME, et al. (2014) Oxidative stress status in nutritionally stunted children, Egypt. Pediatr Assoc Gazette 62 28-33.

2. 2. Monteiro CA, Benicio MH, Conde $\mathrm{WL}$, Konno S, Lovadino AL, et al. (2010) Narrowing socioeconomic inequality in child stunting: the Brazilian experience 1974-2007. Bull World Health Organ 88: 305-311.

3. Willcox JK, Ash SL, Catignani GL (2004) Antioxidants and prevention of chronic disease. Review Crit Rev Food Sci Nutr 44: 275-295.

4. G Oboh, IA Akinbola, AO Ademosun, DM Sanni, OV Odubanjo (2015) Essential Oil from Clove Bud (Eugenia aromatica Kuntze) Inhibit Key Enzymes Relevan to the Management of Type-2 Diabetes and Some Pro-oxidant Induced Lipid Peroxidation in Rats Pancreas in vitro. J Oleo Sci 64: 775-782.

5. Valko M, Leibfritz D, Moncol J, Cronin MT, Mazur M, et al. (2007) Free radicals and antioxidants in normal physiological functions and human disease. Int $J$ Biochem Cell Biol 39: 44-84.

6. Miller DD, Welch RM (2013) Food system strategies for preventing micronutrient malnutrition. Food policy 42: 115-128.

7. Chinma CE, Gernah DI (2007) Physicochemical and sensory properties of cookies produced from cassava/ soyabean/mango composite flours. J Raw Mat Res 4: 32-43.

8. Awadalkareem AM, Mustafa Al, El Tinay AH (2008) Protein, Mineral Content and Amino Acid Profile of Sorghum Flour as Influenced by Soybean Protein Concentrate Supplementation. Pakistan Journal of Nutrition 7: 475-479.

9. Rahaie S, Mohammad S, Gharibzahedi T, Razavi SH, Jafari SM (2014) Recent developments on new formulations basedon nutrient-dense ingredients for the production of healthy-functional bread: a review. J Food Sci and Tech 51: 28962906.

10. Ayo JA, Ayo VA, Nkama I, Adewori R (2007) Physicochemical, in vitro digestibility and organoleptic evaluation of "Acha" wheat biscuits supplemented with soya bean flour. Nigeria Food journal 25: 77-89.

11. AOAC (2010) Official Methods of Analysis. (20th edtn), Association of Official Analytical Chemists. Washington, DC.

12. 12. Ihekoronye, Al, Ngoddy PO (1985) Integrated Food Science and Technology for the Tropics, Macmillan Publishers, London, UK.

13. Friedwald WT, Levy RT, Frederickson DS (1972) Estimation of the concentration of low lipoprotein cholesterol in plasma without use of preparative ultracentrifuge. Clin Chem 18: 499-502.

14. Aebi HE (1983) Methods in Enzymatic Analysis, Academic press, New York.

15. Misra H, Fridovich I (1972) The role of superoxide anion in the autoxidation of epinephrine and a simple assay for superoxide dismutase. J Biol Chem 247 3170.

16. Ellman GL (1959) Tissue sulphydryl groups. Arch Biochem Biophys 32: 70-77.

17. Erukainure OL, Ebuehi OA, Adeboyejo FO, Aliyu MC, Elemo GN (2013) 
Citation: Oluwole OB, Elemo GN, Kosoko SB, Adeyoju A, Oyegbami F, et al. (2015) Nutritional Properties and Toxicological Assessment of High Nutrient Biscuit Developed from Blends of Some Cereals and Legume. J Nutr Disorders Ther 5: 176. doi:10.4172/2161- 0509.1000176

Hematological and biochemical changes in diabetic rats fed with fiber-enriched cake. Journal of Acute Medicine 3: 39-44.

18. Garg M, Garg C, Dhar VJ, Kalia AN (2010) Standardized Alcoholic extract of Phyllanthus fraternus exerts potential action against disturbed biochemical parameters in diabetic rats. African J Bioch Res 4:186-190.

19. Mizuno A, Uematsu T, Gotoh S, Katoh E, Nakashima M (1996) The measurement of caffeine concentration in scalp hair as an indicator of liver function. J Pharm Pharmacol 48: 660-664.

20. Rosalki SB, Mcintyre N (1999) Biochemical investigations in the management of liver disease. Oxford textbook of clinical hepatology, (2nd edtn) New York, Oxford University press, 503-521.

21. Fevery J (2008) Bilirubin in clinical practice: a review. Liver Int 28: 592-605.

22. Nikkhila EA, Kekki M (1973) Plasma triacylglycerol transport kinetics in diabetes mellitus. Metabolism 22: 1-22.

23. 23. Chaterjee MN, Shinde R (1994) Metabolism of carbohydrates Part-II, Text book of Medical Biochemistry, JayPee brothers Medical Publishers Pvt Ltd 421-430.

24. Murray RK, Granner DK, Mayes PA, Rowell VW (2000) Harpers Biochemistry, (25th edtn) Stanford CT, Appleton and Lange 610-617.

25. Saliu JK, Bawa-Allah KA (2012) Toxicological Effects of Lead and Zinc on the Antioxidant Enzyme Activities of Post Juvenile Clarias gariepinus. Resources and Environment 2: 21-26.

26. Esterbauer H, Gebicki J, Puhl H, Ju“ gens G (1992) The role of lipid peroxidation and antioxidants in oxidative modification of LDL. Free Radic Biol Med 13: 341 90 .

27. Matés JM, Pérez-Gómez C, deCastro IN (1999) Antioxidant Enzymes and Human Diseases. Clinical Biochemistry 32: 595-603.

28. Nwozo SO, Oyinloye BE (2011) Hepatoprotective effect of aqueous extract of Aframomum meleguetaon ethanol-induced toxicity in rats. Acta Biochimica Polonica 58: 355-358. 